\title{
Processing of Mercury-Stibium Gold Bearing Ore of Djijikrut Deposit
}

\author{
Mahsuda Abdusalyamova ${ }^{1}$, David Dreisinger ${ }^{2}$, Zinaida Zinchenko ${ }^{1}$, Petr Solozhenkin ${ }^{3}$, Safarali Gadoev ${ }^{1}$, Ivan \\ Tyumin $^{1}$ and Marhabo Ismailova ${ }^{1}$ \\ 1. V.I. Nikitin Institute of Chemistry, Academy of Science of the Republic Tajikistan, Dushanbe 734063, Tajikistan \\ 2. Department of Materials Engineering, University of British Columbia, Vancouver 3096350, Canada \\ 3. IPKON the RASci (Institute of Comprehensive Exploitation of Mineral Resources of the Russian Academy of Science), Moscow \\ 111020, Russia
}

Received: February 23, 2013 / Accepted: April 23, 2013 / Published: May 20, 2013.

\begin{abstract}
The mercury-antimony-gold ore was subjected of the flotation. As a result of enrichment of ore, the mercury-antimony concentrate with the contents of $51.5 \% \mathrm{Sb}, 3.55 \% \mathrm{Hg}$ and $6 \mathrm{~g} / \mathrm{t} \mathrm{Au}$ was received. Vacuum distillation of concentrate allocation in serial sublimates mercury and antimony was designed. The big amount gold passed to calcine after vacuum distillation. The gold in calcine roasting up to $900{ }^{\circ} \mathrm{C}$ was $30.6 \mathrm{~g} / \mathrm{t}$.
\end{abstract}

Key words: Ore, concentrate, flotation, cyanidation, roasting, mercury, antimony, gold.

\section{Introduction}

Tajikistan is rich in mercury-antimony deposits (Scalnoe, Djijikrut, etc.). The Republic takes the second place in the countries by having antimony resources and the fourth place in the world. Antimony-mercury ores of Djijikrut deposits are processed at Anzob (Tajikistan) by flotation to produce a mercury-antimony concentrate. However, for the lower horizons of the field, we can observe a sharp increase in the content of antimony, mercury, and gold which content is already more than $2 \mathrm{~g} / \mathrm{t}$ in the ore. There are about 6.9 million tons of gold ore and 14 tons of gold in it.

Gold in these ores is presented in the form of nanoscale particles. Size of individual gold particles is about $2.8 \mu \mathrm{m}$.

All these predetermine the research on complex processing of the ores. The technology of complex processing of antimony-gold and gold-antimony ore must be based on the combined scheme in which the

Corresponding author: Mahsuda Abdusalyamova, professor, main research fields: pnictides rare earth elements. E-mail: amahsuda@mail.ru. elements of the "golden" and "antimony" technology are closely intertwined and complement each other, providing maximum extraction of both valuable components [1].

In the balance of the distribution of securities and associated components of the ore deposits Djijikrut, it was found that the same minerals are both hubs and carriers of certain elements. Thus, the hub and carrier of antimony is antimonite, mercury-cinnabar, hubs, and partly carriers of gold, silver, thallium, selenium, marcasite and pyrite. The main carrier of gold is non-metal raw materials of breccias.

Carbonaceous substance is widely spread in the deposit both in ore-bearing rocks and in the ores. There are two major associations, bearing gold: early carbonaceous-carbonate with sulfides (first sedimentary-digenetic type ores) and late gold-cinnabar-calcite (third type of supergene ore). Inclusions of early paragenesis gold are installed, mostly in clastic rocks.

A detailed study of mercury-antimony ores in polished sections showed that the inclusions of native gold are confined primarily to the remnants of clastic 
rocks, without showing the structural-textural subordination of antimony-quartz-dolomite breccia cement. The main quantity of gold in the ore falls along with the host breccias, which have undergone a phase of repetition changes till antimony period. This conclusion is consistent with the conclusion of the researchers on the scattering of $88.1 \%$ of non-metallic minerals, gold, and with the conclusion made by technologists about association of $48 \%-76 \%$ gold with non-metallic minerals.

The main hubs of gold are arsenopyrite and pyrite, forming a close intergrowths with marcasite. At an average content of pyrite and marcasite $1.4 \%$ in the ore in the balance of their share of gold is $12.5 \%$. This is due to low concentrations of minerals in the ore (average $0.2 \%$ ).

Thus, the main minerals of pyrite-marcasite-arsenopyrite, being the hub of gold, are not their carriers, i.e., they borrow it from the surrounding rocks. The role of quartz and dolomite in the distribution of gold is low in a very low content of gold in them.

\section{Materials and Methods}

Ore sample was investigated in which the metal content was: $\mathrm{Sb}-3.8 \% ; \mathrm{Hg}-0.4 \% ; \mathrm{Au}-2.5 \mathrm{~g} / \mathrm{t}$; $\mathrm{Tl}-29 \mathrm{~g} / \mathrm{t} ; \mathrm{Se}-12 \mathrm{~g} / \mathrm{t} ; \mathrm{Te}-14 \mathrm{~g} / \mathrm{t}$. Flotation was carried out in a mechanical flotation device with $250 \mathrm{~g}$ hinges. Nonionic low-toxicity surfactants were used as flotation reagents. Grade 4 toxicity and hazards, such as "Oksafor-1107" (O-1107), "Pemisol" and butyl xanthate, lead nitrate, frother-T-80, Formula O-1107 is shown on Fig. 1. "Pemisol" has the following composition: kumilfenol-1.5\%-15\%, the fraction of aromatic hydrocarbons with a boiling point of $135{ }^{\circ} \mathrm{C}-154{ }^{\circ} \mathrm{C}$ beginning and the end of the boil

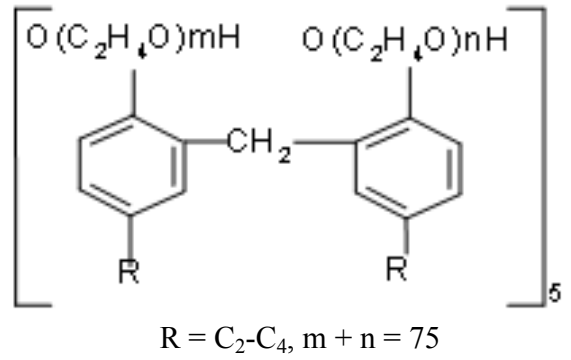

Fig. 1 Formula of Oksafor-1107.

$164{ }^{\circ} \mathrm{C}-270{ }^{\circ} \mathrm{C}-70 \%$, non-ionic SAS-OP-10-15-28.5\%.

Brand UV-visible spectrophotometer was used to record the spectrum of absorption. The characteristic band for xanthate is located in the field of $301 \mathrm{~nm}$, O-1107 and "Pemisol"-289 nm. X-ray analysis was recorded on the device "Dron-3M".

Cyanidation was carried out in bottles fitted with a tube for access to air, rotating continuously on the rolls, which made it possible to carry out the leaching process without using special oxidizing agents, such as barium peroxide, hydrogen peroxide, etc.. Weight of tailings in the experiments is $200 \mathrm{~g}$. The ratio of $\mathrm{S}: \mathrm{L}$ is $1: 1.5$. Leaching time is $24 \mathrm{~h}$. During the leaching $\mathrm{pH}$ of the pulp was maintained in the range 10.5-11.5 with lime. Gold in solution was identified with atomic absorption spectroscopy.

\section{Results and Discussion}

\subsection{Technological Researches of Ore}

The technological scheme of flotation includes rougher, two scavenging and two cleaner flotation with extraction of antimony-87.5\%, mercury-96.3\%, thallium-62.4\%, selenium-58.9\%, tellurium-31.7\% . Extraction of gold into mercury-antimony concentrate was $30 \%$. The gold content in tailings of flotation is 1.7-1.8 g/t [2]. The distribution of metal in the products of enrichment is given in Table 1.

Table 1 The flotation of antimony ore in closed cycle.

\begin{tabular}{|c|c|c|c|c|c|c|c|c|c|c|c|c|c|}
\hline \multirow{2}{*}{ Name of product } & \multirow{2}{*}{ Yield (\%) } & \multicolumn{6}{|c|}{ Content $(\%)$} & \multicolumn{6}{|c|}{ Recovery (\%) } \\
\hline & & $\mathrm{Sb}$ & $\mathrm{Hg}$ & $\mathrm{Tl}(\mathrm{g} / \mathrm{t})$ & $\mathrm{Se}(\mathrm{g} / \mathrm{t})$ & $\operatorname{Te}(\mathrm{g} / \mathrm{t})$ & $\mathrm{Au}(\mathrm{g} / \mathrm{t})$ & $\mathrm{Sb}$ & $\mathrm{Hg}$ & $\mathrm{Tl}$ & $\mathrm{Se}$ & $\mathrm{Te}$ & $\mathrm{Au}$ \\
\hline Concentrate & 5.96 & 40.7 & 4.11 & 256.6 & 108.6 & 57.1 & 12 & 87.45 & 96.3 & 62.4 & 58.9 & 31.7 & 30.9 \\
\hline Tailings & 94.04 & 0.37 & 0.01 & 9.8 & 4.8 & 7.8 & 1.7 & 12.55 & 3.7 & 37.6 & 41.1 & 68.3 & 69.1 \\
\hline Ore & 100.0 & 2.8 & 0.25 & 24.5 & 11.0 & 10.7 & 2.3 & 100 & 100 & 100 & 100 & 100 & 100 \\
\hline
\end{tabular}


Typically, in industrial practice the xanthogenate is used as a collector to enrich antimony ores with pre-activation of antimonite by lead cations [3]. Cations of lead sorptioning on the mineral surface soil concentrate and prevent at metallurgical processing. In addition, lead nitrate is a highly toxic agent that negatively affects the environment. We proposed to use low-toxicity nonionic surface active agents which suggest excluding lead nitrate from the process. The test reagents are small toxic surface-active agents (Grade 4 toxicity and hazards), such as “Oksafor-1107" (O-1107), “Oksafor-43”, "Pemisol”. These reagents are widely used in the practice of flotation. O-1107 and "Pemisol" were studied in the flotation of the ore samples. Diphyllic structure of molecules O-1107 predetermines surface activity of this reagent on the boundary surface of liquid-gas, that is demonstrated in its foaming capacity. Effective use of surfactants has been confirmed by us in the flotation of antimony-arsenic ore deposit "Scalnoe" [4]. Previously, we have installed a synergistic effect of studied SAS and butyl xanthate. The binary mixtures of these reagents have been studied on this basis. Table 2 shows the results of the flotation, which suggests that the studied mixtures of chemicals are effective and allow you to refuse from using toxic activator-lead nitrate.

It is known that at the flotation of antimonite by SAS, coordination compounds are formed on its surface. The electron source is the oxygen of ethylene oxide surfactants, and antimony acid, which is formed on the surface of antimonite that is able to attach electrons. Chernikh et al. [5], using electron paramagnetic resonance formation of complexes with charge transfer between the "Oksafor-1107" and strong acceptors benzoquinone is shown, indicating the donor ability of "Oksafor" and the formation of adducts between the xanthate and surface-active substances. To study the synergistic of these reagents the researches have been conducted on their sorption on the surface of antimonite. Sorption of xanthate reduces with increasing concentration of surfactants, indicating the joint sorption of reagents on the surface of minerals (Fig. 2). Obtained results confirm the synergies of the mixtures of reagents.

\subsection{Development of Technology for Extracting Gold from the Flotation Tailings}

Further studies have been devoted to studying hydrometallurgical leaching of gold by cyanide. The apparatus was mounted for continuous ongoing process. The concentration of $\mathrm{NaCN}$ in the experiments was $0.05 \%-0.1 \%, \mathrm{pH}$ was maintained at 10.3-10.6 by adding lime. $2,4,8,24 \mathrm{~h}$ later after the start of the experiment stirring was stopped, to take the sampling aliquots of the slurry $(20 \mathrm{~mL})$ to determine the $\mathrm{pH}$, the concentration of free $\mathrm{NaCN}$ and concentration of gold. Gold in solution was determined by atomic absorption spectroscopy. Tailings of

Table 2 The flotation of mercury-stibium ore by binary mixture of Xanthogenate $(300 \mathrm{~g} / \mathrm{t})$ with "Oksafore-1107" and "Pemisol".

\begin{tabular}{lcclrr}
\hline \multirow{2}{*}{ Name of product } & Yield & \multicolumn{2}{c}{ Content (\%) } & \multicolumn{2}{c}{ Recovery (\%) } \\
\cline { 2 - 6 } & (\%) & $\mathrm{Sb}$ & $\mathrm{Hg}$ & $\mathrm{Sb}$ & \multicolumn{1}{l}{$\mathrm{Hg}$} \\
\hline Concentrate & 7.46 & 45.46 & 3.64 & 94.82 & 93.91 \\
Tailings & 92.54 & 0.2 & 0.019 & 5.18 & 6.09 \\
Ore & 100.00 & 3.57 & 0.29 & 100.00 & 100.00 \\
\hline \multicolumn{5}{c}{ "Pemisol" $-400 \mathrm{~g} / \mathrm{t}$} \\
\hline Concentrate & 7.65 & 42.6 & 3.32 & 90.28 & 94.18 \\
Tailings & 92.35 & 0.38 & 0.017 & 9.72 & 5.82 \\
Ore & 100.0 & 3.61 & 0.27 & 100.0 & 100.00 \\
\hline
\end{tabular}

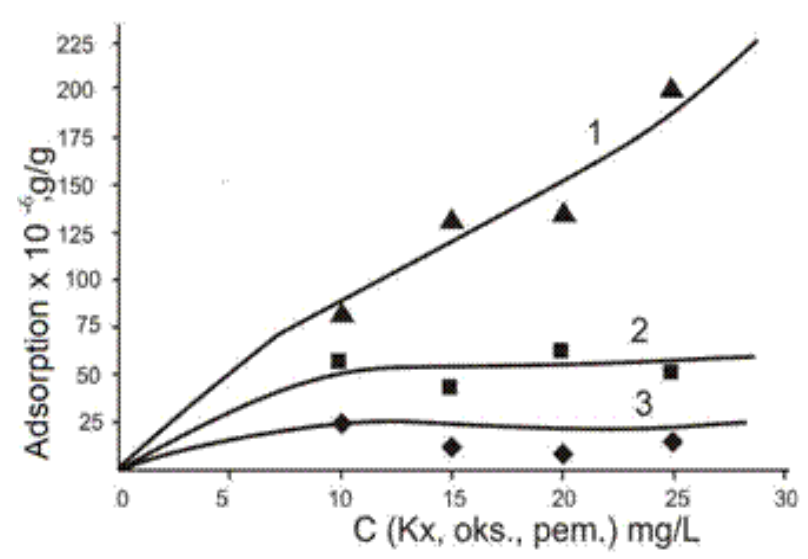

Fig. 2 Change of xanthogenate adsorption (Kx) on antimonite of reagents concentration: $1-K x ; 2-K x+$ "O-1107"; 3-Kx + "Pemisol". 
flotation was established by cyanidation: 1) an increase in cyanide concentration of $0.1 \%$ has a positive effect on the extraction of gold, a further increase in concentration has no appreciable effect on the cyanidation process; (2) Regrinding flotation tailings fineness up to $94 \%$ of the class " $-0.063 \mathrm{~mm}$ " makes it possible to reveal several gold, located in intergrowths, resulting in the increase of dissolution rate of gold. It was determined that an increase in the duration of the leaching of up to $48 \mathrm{~h}$ not only increases the extraction of Au to solution, but on the contrary, starting from $4 \mathrm{~h}$ after the start of the experiment, we can observe a decrease in the concentration of $\mathrm{Au}$ in solution, which can be explained by the presence of carbonaceous materials in the ore. Processing of carbonaceous ore has its own characteristics [6]. Carbonaceous or graphite sludge can adsorb dissolved gold and thereby impede the process of cyanidation. In order to reduce their impact, experiments were conducted with the change of the leach solution by the method of 3 -stage-cyanide. As a result of the experiments, the total recovery of gold to the solution of the third stage of cyanide slightly increased and amounted to $48.5 \%$. One way to reduce the negative impact of carbonaceous materials on the process of cyanide is pre-treatment of the material by kerosene. Treatment by kerosene prevented the sorption of gold by carbonaceous matter, but the recovery of gold remained low. In order to improve the cyanide process, the samples of flotation tailings were subjected to roasting at a temperature of $300{ }^{\circ} \mathrm{C}$ at different duration time. It is well known the low-temperature roasting of gold ores as a preparatory operation before cyanidation. Roasting is carried out at a temperature of $300-400{ }^{\circ} \mathrm{C}$, which allows to increase gold extraction at subsequent cyanidation. This is due to better disclosure of the metal, due to cracking of the ore during roasting and due to the destruction of the integumentary structures on gold. Coatings on gold, which consisting of iron and manganese hydroxides, lost crystallization water and disintegrated after calcination. From roasted tailings for $3 \mathrm{~h}$, maximum gold extraction $-41.5 \%$ was achieved. Considering the fact that gold is finely dispersed in the sample and related to host rock, tailings of the samples were regrinded to $95 \%$ of the class "- $-0.08 \mathrm{~mm}$ ", and then were subjected to roasting under conditions similar to the previous experiments. Fine grinding improves slightly opening of gold, but increases the rate of gold leaching. After $8 \mathrm{~h}$ of cyanidation and roasting for $2 \mathrm{~h}$, $43.2 \%$ of gold goes to the solution. Increasing the roasting time up to $24 \mathrm{~h}$ does not affect the gold extraction. Oxidative roasting followed by cyanidation of calcine is one of the most common methods of processing of sulphide gold concentrates [7]. Gold-bearing sulfides were oxidized and converted into a porous oxides which well-permeable for cyanide solutions. Subsequent leaching of calcine allows to transfer the opening gold to cyanide solution. In ores of Djijikrut deposit, the main hubs of gold are arsenopyrite and pyrite, forming a close intergrowth with marcasite. Therefore, we carried out the oxidative roasting of tailings. The oxidation of pyrite begins at a temperature of $450-500{ }^{\circ} \mathrm{C}$. The process proceeds with the formation of an intermediate product pyrrotine, which is oxidized to magnetite and further to hematite:

$$
\begin{gathered}
\mathrm{FeS}_{2}+\mathrm{O}_{2}=\mathrm{FeS}+\mathrm{SO}_{2} \\
3 \mathrm{FeS}+5 \mathrm{O}_{2}=\mathrm{Fe}_{3} \mathrm{O}_{4}+3 \mathrm{SO}_{2} \\
4 \mathrm{Fe}_{3} \mathrm{O}_{4}+\mathrm{O}_{2}=6 \mathrm{Fe}_{2} \mathrm{O}_{3}
\end{gathered}
$$

At temperatures above $600{ }^{\circ} \mathrm{C}$, oxidation of pyrite precedes its dissociation with the formation of pyrrotine:

$$
2 \mathrm{FeS}_{2}=2 \mathrm{FeS}+\mathrm{S}_{2}
$$

\subsection{Cyanidation of Tailings}

After $2 \mathrm{~h}$ roasting, samples of tailings were subjected to cyanidation. Cyanidation was carried out at a supported cyanide concentration- $0.1 \%$. Duration of cyanidation in all experiments was $24 \mathrm{~h}$. Effect of roasting temperature on the leaching of gold from the tailings is shown in Table 3. As can be seen from the data, the optimum of tailings roasting temperature is 
Table 3 Influence of roasting temperature on the results of tailings cyanidation.

\begin{tabular}{lrrrl}
\hline $\begin{array}{l}\mathrm{T}_{\text {Roasting }} \\
\left({ }^{\circ} \mathrm{C}\right)\end{array}$ & \multicolumn{1}{c}{ Time } & \multirow{2}{*}{$\mathrm{pH}$} & \multicolumn{2}{c}{ Concentration of $\mathrm{Au}$ Recovery } \\
& $(\mathrm{h})$ & \multicolumn{1}{c}{ in solution $(\mathrm{mg} / \mathrm{L})$} & $\mathrm{Au}(\%)$ \\
\hline \multirow{3}{*}{300} & 2 & 10.4 & 0.50 & 44.1 \\
& 4 & 10.3 & 0.54 & 47.6 \\
& 8 & 9.9 & 0.50 & 44.1 \\
& 24 & 9.8 & 0.47 & 41.5 \\
\hline \multirow{4}{*}{400} & 2 & 10.0 & 0.52 & 45.9 \\
& 4 & 9.9 & 0.53 & 46.7 \\
& 8 & 10.0 & 0.53 & 46.7 \\
& 24 & 9.8 & 0.47 & 41.5 \\
\hline \multirow{4}{*}{600} & 2 & 11.2 & 1.19 & 99.1 \\
& 4 & 11.4 & 1.19 & 99.1 \\
& 8 & 11.4 & 1.15 & 95.8 \\
& 24 & 11.4 & 1.01 & 84.2 \\
\hline \multirow{3}{*}{750} & 2 & 12.0 & 0.96 & 84.7 \\
& 4 & 11.9 & 1.01 & 89.2 \\
& 8 & 11.9 & 1.00 & 88.2 \\
\hline
\end{tabular}

$600{ }^{\circ} \mathrm{C}$. In this case, almost all gold transfers to the solution. Temperature increase to $750{ }^{\circ} \mathrm{C}$ reduces the extraction of gold, which is consistent with literature data. It should be noted that after roasting sharply increases the rate of dissolution of gold for $2 \mathrm{~h}$, gold recovery to solution is $99.1 \%$.

\subsection{The Leaching of Gold by Thiourea}

According to its technological data, the leaching method which is presently applied to extract gold from ores is rather a complete process, however, it has negative feature as cyanic compounds used for this purpose are too toxic. Therefore, the objective of the present work is to test thiourea solution as a substitute for cyanic solvents of gold [8].
Gold dilution process in the solutions of thiourea runs according to the following reaction:

$$
\mathrm{Au}+2 \mathrm{CS}\left(\mathrm{NH}_{2}\right)_{2} \leftrightarrow\left[\mathrm{Au}\left\{\mathrm{CS}\left(\mathrm{NH}_{2}\right)_{2}\right\}_{2}\right]^{+}+\mathrm{e}
$$

with instability constant $B=3.2 \times 10^{-26}$, therefore, the gold standard potential decreases up to $+0.38 \mathrm{~V}$. This is how gold dissolution in aqueous acidic thiourea solutions contained $\mathrm{Fe}^{3+}$ ions as oxidant, which is explained.

As in the case with cyanidation process, the investigations have been made according to ordinary laboratory technique of bottle tests by stirring in open bottles. Tailings were placed in bottle and thiourea and sulfuric acid solutions were added, and in some cases oxidant was added, the stirring was done using rotating disks for the certain period of time. After 2, 4, $8 \mathrm{~h}$ after the initiation of the experience, rotating disks were stopped and aliquot selection $(10 \mathrm{~mL})$ was made to identify $\mathrm{pH}$ and gold concentration. Aliqout loss was compensated by adding the same volume of thiourea solution. The experiments have been carried out with flotation tailings which gold content is 1.8 $\mathrm{g} / \mathrm{t}$.

Thiourea concentration was $0.5 \%$, sulphuric acid was $0.5 \%$, oxidant $\left(\mathrm{H}_{2} \mathrm{O}_{2}\right)$ was $0-0.06 \%$ in the solutions. Ratio of liquid to solid was $1.5 \%$.

The results of leaching experiments carried out both in the presence of oxidant and without it were presented in Table 4. Gold extraction to the solution is unsatisfactory and does not exceed $21.3 \%$. $\mathrm{pH}=6,4$ leaching solution was after stirring with tailings was, that is not optimal condition to carry out thiourea

Table 4 Leaching of flotation tailings with thiourea in the presence of an oxidant.

\begin{tabular}{|c|c|c|c|c|c|c|c|c|c|}
\hline \multirow[b]{2}{*}{ Time (h) } & \multicolumn{5}{|c|}{ Supplements } & \multirow{2}{*}{$\begin{array}{l}\text { Solution } \\
\mathrm{pH}\end{array}$} & \multicolumn{3}{|c|}{$\begin{array}{c}\text { Extracting } \\
\mathrm{Au}\end{array}$} \\
\hline & Ore $(\mathrm{g})$ & Water $(\mathrm{mL})$ & $\mathrm{CS}\left(\mathrm{NH}_{2}\right)_{2}(\mathrm{~g})$ & $\begin{array}{l}\mathrm{H}_{2} \mathrm{SO}_{4} \\
\text { (conc.) } \\
\text { (mL) }\end{array}$ & $\begin{array}{l}\mathrm{H}_{2} \mathrm{O}_{2}-3 \% \\
(\mathrm{~mL})\end{array}$ & & $\begin{array}{l}\mathrm{Au} \\
(\mathrm{mg} / \mathrm{L})\end{array}$ & $g / t$ & $\%$ \\
\hline Start & 200 & 300 & 1.5 & 1.5 & 6 & & & & \\
\hline 2 & & & & & & 6.5 & 0.21 & 0.315 & 17.5 \\
\hline 4 & & & & & & 6.4 & 0.215 & 0.322 & 17.8 \\
\hline 8 & & & & & & 6.4 & 0.208 & 0.312 & 17.3 \\
\hline
\end{tabular}

pH of leaching solution $=1.5$;

Original content of $\mathrm{Au}$ in the flotation tailings $=1.8 \mathrm{~g} / \mathrm{t}$. 
Table 5 The results of thiourea leaching of gold from burnt tails after their processing with sulfuric acid.

\begin{tabular}{|c|c|c|c|c|c|c|c|c|c|}
\hline \multirow[b]{2}{*}{ Time (h) } & \multicolumn{5}{|c|}{ Additives } & \multicolumn{2}{|c|}{ Solution } & \multicolumn{2}{|c|}{ Extracting $\mathrm{Au}$} \\
\hline & Ore $(g)$ & Water $(\mathrm{mL})$ & $\mathrm{CS}\left(\mathrm{NH}_{2}\right)_{2}(\mathrm{~g})$ & $\mathrm{H}_{2} \mathrm{SO}_{4}$ (conc.) (mL) & $\mathrm{H}_{2} \mathrm{O}_{2}-3 \%(\mathrm{~mL})$ & $\mathrm{pH}$ & $\begin{array}{l}\mathrm{Au} \\
(\mathrm{mg} / \mathrm{L})\end{array}$ & $\begin{array}{l}\mathrm{Au} \\
\mathrm{g} / \mathrm{t}\end{array}$ & $\begin{array}{l}\mathrm{Au} \\
\%\end{array}$ \\
\hline Start & 200 & 300 & 1.5 & 1.5 & & & & & \\
\hline 2 & & & & & & 2.1 & 1.030 & 1.54 & 85.8 \\
\hline 4 & & & 0.5 & & & 4.0 & 1.040 & 1.56 & 86.6 \\
\hline 8 & & & & & & 3.0 & 1.050 & 1.57 & 87.5 \\
\hline
\end{tabular}

The oxidant-air.

leaching and that is presumably explained by the presence of acid-soluable minerals in tailings. This did not allow reducing $\mathrm{pH}$ medium to the required values. Therefore, ore was previously subjected to acidulation by sulphuric acid while stirring for $6 \mathrm{~h}$.

Thus, in further experiments on thiourea leaching of gold the tailings flotation, the last acid treatment did not interact with sulfuric acid to be added to create an acidic environment, and $\mathrm{pH}$ during the experiments remained to be $2-4$.

Thiourea leaching of gold from the flotation tailings discovered that the extraction of gold in solution did not exceed 39.5\%. These results leaching were as presence of hydrogen peroxide, acting as an oxidant, and as without it. Therefore, in subsequent experiments, hydrogen peroxide has not been feed. Oxidant was atmospheric oxygen. The tails, baked for $2 \mathrm{~h}$ at temperatures of $400{ }^{\circ} \mathrm{C}$ and $600{ }^{\circ} \mathrm{C}$.

The gold extracted in solution after baking at $600^{\circ} \mathrm{C}$ without acid $48.8 \%$.

Only after acid processing and subsequently baking at $600{ }^{\circ} \mathrm{C}$ in $8 \mathrm{~h} 87.5 \%$ of gold was extracted into the solution (Table 5).

\section{Physico-Chemical Basis of the Vacuum Distillation of Antimony-Mercury Gold Bearing Concentrates of Djijikrut Deposit}

Antimony-mercury gold bearing concentrate contained 52.5\% Sb, 4.1\% Hg, $6 \mathrm{~g} / \mathrm{t} \mathrm{Au}$ and $259.6 \mathrm{~g} / \mathrm{t}$. $\mathrm{Tl}$ have been used X-ray analysis of the concentrate showed that main part of antimony is represented by mineral antimonite $\left(\mathrm{Sb}_{2} \mathrm{~S}_{3}\right)$, and mercury-cinnabar (HgS). Mercury from concentrates is obtained mainly by pyrometallurgical method [9]. Pyrometallurgical process for the preparation of mercury is reduced to two methods: distillation roasting of mercury concentrate and subsequent condensation of mercury vapor and furnace gases. Despite the simplicity of the process, this method is dangerous for both staff and the environment.

In this regard, a method was developed for the separation of antimony and mercury by vacuum-thermal distillation of mercury. This method is based on the difference between saturated vapor pressure of mercury, cinnabar, and antimonite [10, 11]. Fig. 3 shows the experimental apparatus assembled for this purpose. Studies have been conducted on the effect of temperature, duration of the process, the residual pressure on the sublimation of mercury. The mercury volatilizes efficiently and selectively at $300^{\circ} \mathrm{C}$, residual pressure $0.79 \times 10^{-4} \mathrm{~Pa}$ for $20-25 \mathrm{~min}$ (Table 6). Calcine of the distillation of mercury was analyzed by chemical, thermal, and X-ray phase analysis methods. Fig. 4 shows the resulting X-ray spectrum. As can be seen from Fig. 4, after vacuum sublimation of mercury the lines of cinnabar are absent in X-ray spectrum. Thermal analysis revealed a peak at $531{ }^{\circ} \mathrm{C}$, which corresponds to the melting temperature of the mineral antimonite (melting $\left.\mathrm{Sb}_{2} \mathrm{~S}_{3}-540{ }^{\circ} \mathrm{C}\right)$.

The resulting calcine contains $58.7 \%$ of antimony, $0.011 \%$ of thallium, $0.22 \%$ of arsenic, 5.8 $\mathrm{g} / \mathrm{t}$ of gold. 


\section{Pyroselection of Calcine after a Preliminary Distillation of the Mercury}

Gold-arsenic and gold-antimony concentrates are complex raw materials, and their processing by existing methods is related with technological difficulties and low yield. When antimony is melting, gold is distributed among all melting products [12]. In connection with this, the special scheme of antimony vacuum sublimation in the form of stibnite and arsenic compounds separately with concentration of gold in residues was developed [11]. Apparatus was collected using fractional condensation of antimonite and arsenic compounds by vacuum distillation (Fig. 5).

In order to study the fractional condensation of sulfides from the calcine the effect of temperature, duration, residual pressure on the separation of sulfide and gold concentrations in it have been studied. Influence of temperature on the degree of sublimation of the volatile components of the calcine was investigated at a residual pressure of $0.013 \times 10^{-4} \mathrm{~Pa}$ for $1 \mathrm{~h}$. Condensate deposited in the form of two rings of different colors after sublimation of calcine. Needle-shaped crystals of dark-silver, almost black in color, reminiscent of single crystals of antimony

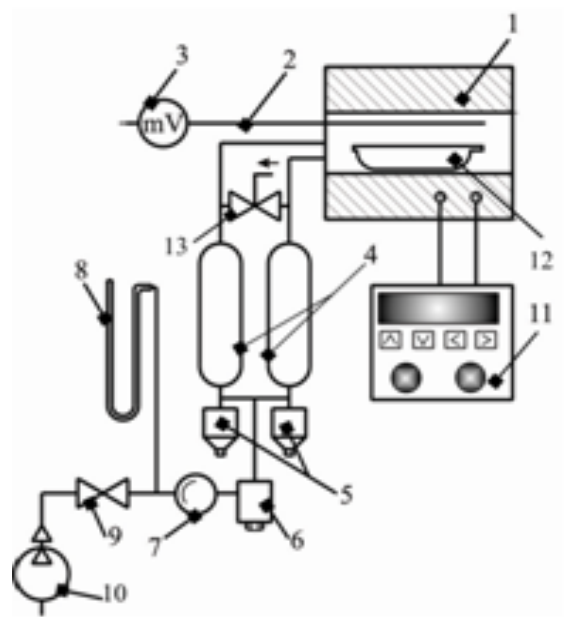

Fig. 3 The experimental equipment for the sublimation of mercury from concentrate: 1-tube furnace; 2-thermocouple; 3-millivolt meter; 4-expansion chamber; 5-sewers; 6-filter; 7-manometer; 8 -mercury manometer; 9-valve shut-off; 10-vacuum pump; 11-temperature control; 12-crucible; 13 - exhaust valve.
Table 6 Content of antimony, mercury, thallium and arsenic in calcine after sublimation of mercury depending on residual pressure.

\begin{tabular}{llllll}
\hline No. & $\begin{array}{l}\text { Pressure } \\
\left(\mathrm{Pa} \cdot 10^{-4}\right)\end{array}$ & $\begin{array}{l}\text { Antimony } \\
(\%)\end{array}$ & $\begin{array}{l}\text { Mercury } \\
(\%)\end{array}$ & $\begin{array}{l}\text { Thallium } \\
(\%)\end{array}$ & $\begin{array}{l}\text { Arsenic } \\
(\%)\end{array}$ \\
\hline 1 & 0.013 & 50.52 & - & 0.011 & 0.21 \\
2 & 0.13 & 50.54 & - & 0.011 & 0.21 \\
3 & 0.26 & 54.2 & 0.012 & 0.01 & 0.2 \\
4 & 0.39 & 56.19 & 0.020 & 0.010 & 0.22 \\
5 & 0.53 & 56.27 & 0.024 & 0.011 & 0.23 \\
6 & 0.66 & 56.66 & 0.04 & 0.011 & 0.22 \\
7 & 0.79 & 59.44 & 0.041 & 0.011 & 0.28 \\
\hline
\end{tabular}

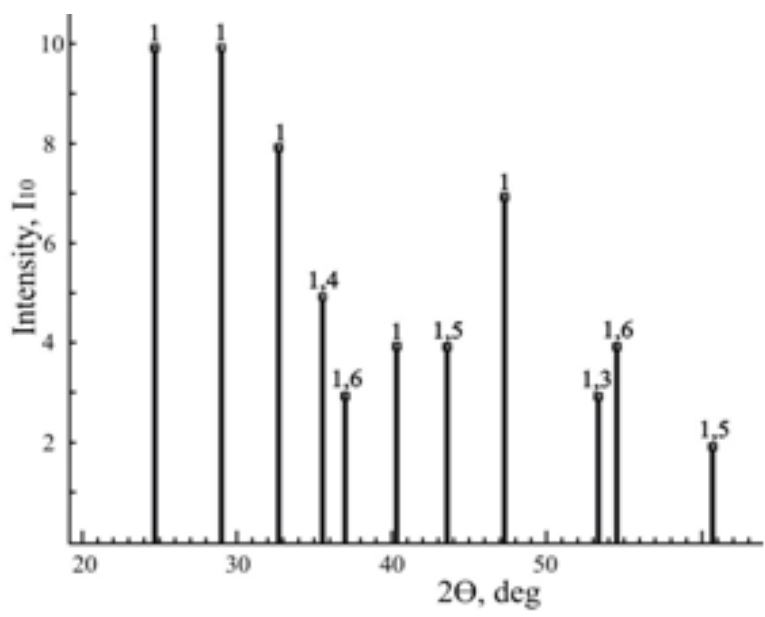

Fig. 4 X-ray calcine produced at $300{ }^{\circ} \mathrm{C}: 1$ - antimonite $\mathrm{Sb}_{2} \mathrm{~S}_{3} ; \quad 3$-aurumpigmentum $\quad \mathrm{As}_{2} \mathrm{~S}_{3} ; \quad 4$-dolomite $\mathrm{CaMg}\left(\mathrm{CO}_{3}\right)_{2} ; 5$-anorthite $\mathrm{Ca}\left\{\mathrm{Al}_{2} \mathrm{Si}_{2} \mathrm{O}_{5}\right\} ; 6$ - thallium natrolite (Tl, $\mathrm{Na})\left\{\mathrm{Al}_{2} \mathrm{Si}_{3} \mathrm{O}_{10}\right\} \cdot 2 \mathrm{H}_{2} \mathrm{O}$.

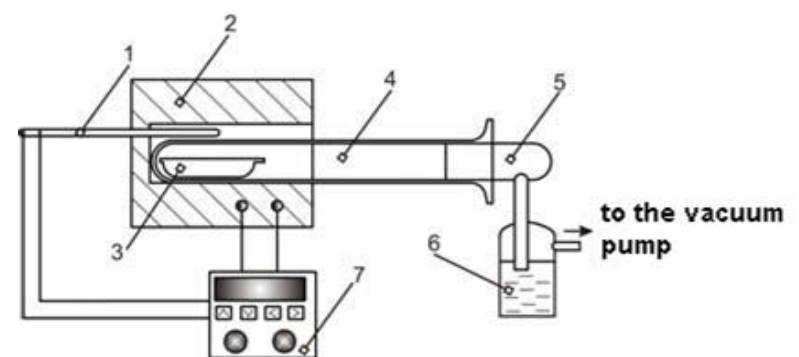

Fig. 5 Equipment of vacuum selection of cinder: 1-TC (thermocouples); 2-tube furnace; 3-crucible; 4-a quartz tube; 5- glass stopper; 6-a trap for the exhaust gas; 7 - temperature controller.

sulfide are deposited in the area of higher temperature. Mixture of arsenic sulfide, sulfur, and traces of stibnite was precipitated in the colder parts of the condensate of orange color. X-ray spectrum of condensation indicates the selective allocation of stibnite from the calcine. X-ray and silicate analysis of 
the cinder at $900{ }^{\circ} \mathrm{C}$ showed the content of mostly silicates. Table 7 shows the material balance of sublimation process. The content of antimony in the residue decreased with increasing temperature from $700{ }^{\circ} \mathrm{C}$ to $900{ }^{\circ} \mathrm{C}$ from $14 \%$ to $2.63 \%$, and the degree of sublimation of antimony, respectively, increased from $97 \%$ to $99.6 \%$.

The sulfur content decreased from $8.93 \%$ to $8.67 \%$, and the degree of sublimation of $94.4 \%$ to $95.8 \%$. The distribution of $\mathrm{Au}, \mathrm{Ag}$ in the cinder, depending on temperature, is shown in Table 8 . The content of $\mathrm{Au}$ and $\mathrm{Ag}$ in the residue was determined by atomic absorption method. Thus, the vacuum distillation of antimony-mercury gold bearing concentrates of Djijikrut deposit and pyroselection of calcine after preliminary mercury sublimation allowed us to obtain commercial qualitative mercury and antimony products.

\section{Investigation of Stibnite Oxidation Process in Furnace of Boiling Bed}

Technological processes in furnaces of boiling bed are often applied to process oxidizing ores and concentrates. Antimony sulfide oxidation study from stibnite was carried in the furnace of boiling bed.

Oxidation mechanism of sulfides of different metals up to present time can not be considered being investigated completely. Mainly, there are two theories that explain sulfide oxidation mechanism. According to one (sulphate) theory, sulfide oxidation runs through intermediate phase-sulphate formation, metal and sulfur oxides are obtained in the result of sulphate decomposition. Depending on temperature and condensate of sulfurous anhydride in gaseous phase the formed oxides can transfer into sulphates again. According to another, (oxide) theory, oxide formation happens directly from sulfides. Many scientists support combined theory. Many researchers have been dealing with antimony sulfide oxidation;

Table 8 Dependence of gold and silver content in cinder on distillation temperature.

\begin{tabular}{lccc}
\hline Temp $\left({ }^{\circ} \mathrm{C}\right)$ & 700 & 800 & 900 \\
\hline Gold $(\mathrm{g} / \mathrm{t})$ & 5.76 & 11.15 & 30.8 \\
Silver $(\mathrm{g} / \mathrm{t})$ & 660 & 1,040 & 1,020 \\
\hline
\end{tabular}

Table 7 Material balance of sublimation process of gold containing antimony calcine.

\begin{tabular}{|c|c|c|c|c|c|c|c|c|c|c|}
\hline \multirow[b]{2}{*}{ No. } & \multirow[b]{2}{*}{ Name } & \multirow[b]{2}{*}{$\begin{array}{l}\text { Temp. } \\
\left({ }^{\circ} \mathrm{C}\right)\end{array}$} & \multirow[b]{2}{*}{ Weight (g) } & \multirow[b]{2}{*}{$\begin{array}{l}\% \text { of calcine } \\
\text { weight }\end{array}$} & \multicolumn{3}{|c|}{ Antimony } & \multicolumn{3}{|c|}{ Sulphur } \\
\hline & & & & & $\begin{array}{l}\text { Content } \\
(\%)\end{array}$ & $\begin{array}{l}\text { Quantity } \\
\text { (g) }\end{array}$ & $\begin{array}{l}\text { \% of } \\
\text { common } \\
\text { quantity }\end{array}$ & $\begin{array}{l}\text { Content } \\
(\%)\end{array}$ & Quantity (g) & $\begin{array}{l}\text { \% of } \\
\text { common } \\
\text { quantity }\end{array}$ \\
\hline \multicolumn{11}{|c|}{ Charged: } \\
\hline 1 & Calcine & - & 7 & 100 & 65.97 & 4.893 & 100 & 17.6 & 1.232 & 100 \\
\hline \multicolumn{11}{|c|}{ Received: } \\
\hline 1 & $\begin{array}{l}\text { Black condensate } \\
\text { (stibnite) }\end{array}$ & & 5.4004 & 77.1486 & 78.69 & 4.2524 & 86.908 & 19.2 & 1.037 & 84.16 \\
\hline 2 & $\begin{array}{l}\text { Orange } \\
\text { condensate }\end{array}$ & 700 & 0.0855 & 1.2214 & 79.75 & 0.0682 & 1.393 & 18.9 & 0.0162 & 1.3116 \\
\hline \multirow[t]{2}{*}{3} & Cinder in crucible & & 0.9117 & 13.024 & 14.09 & 0.1358 & 2.776 & 8.93 & 0.0814 & 6.608 \\
\hline & & & 6.3972 & 91.494 & & 4.4564 & 91.087 & & 1.134 & 92.079 \\
\hline 1 & $\begin{array}{l}\text { Black condensate } \\
\text { (stibnite) }\end{array}$ & & 5.108 & 72.971 & 80 & 4.0864 & 83.515 & 19.2 & 0.9807 & 79.605 \\
\hline 2 & $\begin{array}{l}\text { Orange } \\
\text { condensate }\end{array}$ & 800 & 0.3204 & 4.577 & 80.2 & 0.257 & 5.2524 & 19.1 & 0.0623 & 5.06 \\
\hline \multirow[t]{2}{*}{3} & Cinder in crucible & & 0.7597 & 10.8529 & 11.32 & 0.08593 & 1.756 & 19.2 & 0.07597 & 6.176 \\
\hline & & & 6.1881 & 88.4009 & & 4.42933 & 90.523 & & 1.0506 & 84.665 \\
\hline 1 & $\begin{array}{l}\text { Black condensate } \\
\text { (stibnite) }\end{array}$ & & 4.984 & 71.2 & 80.51 & 4.0126 & 82.006 & 20.8 & 1.037 & 84.145 \\
\hline 2 & $\begin{array}{l}\text { Orange } \\
\text { condensate }\end{array}$ & 900 & 0.422 & 6.029 & 75.13 & 0.317 & 6.4786 & 18.2 & 0.0768 & 6.234 \\
\hline \multirow[t]{2}{*}{3} & Cinder in crucible & & 0.584 & 8.34 & 2.63 & 0.01536 & 0.3139 & 8.67 & 0.0506 & 4.1098 \\
\hline & & & 5.99 & 85.569 & & 4.345 & 88.793 & & 1.1644 & 94.4888 \\
\hline
\end{tabular}


Table 9 Material balance of the oxidation roasting process in boiling layer.

\begin{tabular}{|c|c|c|c|c|c|c|c|c|}
\hline No. & $\begin{array}{l}\text { Roasting } \\
\text { rate }\left({ }^{\circ} \mathrm{C} / \mathrm{h}\right)\end{array}$ & $\begin{array}{l}\text { Stibnite } \\
\text { weight } \\
\text { before and } \\
\text { after roasting } \\
\text { (g) }\end{array}$ & $\begin{array}{l}\text { Sb content } \\
\text { before and } \\
\text { after roasting } \\
(\%)\end{array}$ & $\begin{array}{l}\text { Sb amount } \\
\text { before and } \\
\text { after roasting } \\
\text { (g) }\end{array}$ & $\begin{array}{l}\text { Volatilization of } \\
\text { antimony (\%) }\end{array}$ & $\begin{array}{l}\mathrm{S} \text { content } \\
\text { before and } \\
\text { after roasting } \\
(\%)\end{array}$ & $\begin{array}{l}\text { S amount } \\
\text { before and } \\
\text { after roasting } \\
(\mathrm{g})\end{array}$ & $\begin{array}{l}\text { Volatilization of } \\
\text { sulfur (\%) }\end{array}$ \\
\hline \multirow{2}{*}{1} & \multirow{2}{*}{350} & 4.0023 & 65.97 & 2.6403 & \multirow{2}{*}{9.1} & 17.6 & 0.7 & \multirow{2}{*}{35.7} \\
\hline & & 3.4682 & 69.14 & 2.3979 & & 13.2 & 0.45 & \\
\hline \multirow{2}{*}{2} & \multirow{2}{*}{400} & 4.0075 & 65.97 & 2.6437 & \multirow{2}{*}{7.13} & 17.6 & 0.7 & \multirow{2}{*}{84.8} \\
\hline & & 3.513 & 69.89 & 2.4552 & & 3.04 & 0.10 & \\
\hline \multirow{2}{*}{3} & \multirow{2}{*}{450} & 4.0029 & 65.97 & 2.6407 & \multirow{2}{*}{13.8} & 17.6 & 0.7 & \multirow{2}{*}{92.7} \\
\hline & & 3.2737 & 69.49 & 2.2748 & & 1.57 & 0.51 & \\
\hline \multirow{2}{*}{4} & \multirow{2}{*}{350} & 4.0023 & 65.97 & 2.64 & \multirow{2}{*}{10.6} & 17.6 & 0.7 & \multirow{2}{*}{90.85} \\
\hline & & 3.4101 & 69.49 & 2.36 & & 1.9 & 0.064 & \\
\hline \multirow{2}{*}{5} & \multirow{2}{*}{400} & 4.0034 & 65.97 & 2.64 & \multirow{2}{*}{9.8} & 17.6 & 0.7 & \multirow{2}{*}{82.42} \\
\hline & & 3.4313 & 69.38 & 2.38 & & 3.6 & 0.123 & \\
\hline \multirow{2}{*}{6} & \multirow{2}{*}{450} & 4.0026 & 65.97 & 2.64 & \multirow{2}{*}{17.045} & 17.6 & 0.7 & \multirow{2}{*}{99.27} \\
\hline & & 3.115 & 70.42 & 2.19 & & 1.64 & 0.051 & \\
\hline
\end{tabular}

however, there is no certain opinion on mechanism of this process [13].

The authors found that the antimonite oxidation begins at temperature at about $200{ }^{\circ} \mathrm{C}$ to $300{ }^{\circ} \mathrm{C}$ and runs comparatively slowly and depends on grain size. Shahov and Slobodskoy [14] showed that antimonite oxidation process is $180{ }^{\circ} \mathrm{C}$. They think that up to $400{ }^{\circ} \mathrm{C}$ oxidation runs according to reaction:

$$
2 \mathrm{Sb}_{2} \mathrm{~S}_{3}+9 \mathrm{O}_{2}=2 \mathrm{Sb}_{2} \mathrm{O}_{3}+6 \mathrm{SO}_{2}
$$

However, besides this reaction antimony sulfide oxidation can run along with tetraoxide $\mathrm{Sb}_{2} \mathrm{O}_{4}$ formation, but Zhao [13] insist on the fact that oxidation up to tetraoxide runs after whole sulfide oxidation to trioxide. The best reaction conditions are:

$$
2 \mathrm{Sb}_{2} \mathrm{O}_{3}+\mathrm{O}_{2}=2 \mathrm{Sb}_{2} \mathrm{O}_{4}
$$

temperature at $400{ }^{\circ} \mathrm{C}-500{ }^{\circ} \mathrm{C}$ and air surplus. Trioxide amount decreases and of tetraoxide increases depending on temperature growth. Besides, antimony forms $\mathrm{Sb}_{2} \mathrm{O}_{5}$ with oxigen, which is stable up to $357^{\circ} \mathrm{C}$, with further temperature increase it is decomposed with tetraoxide formation and then trioxide. Antimony tetraoxide decomposes into antimony trioxide and oxygen, when tetraoxide heating. Decomposition starts at $900{ }^{\circ} \mathrm{C}$.

The authors studied oxidation process of the obtained stibnites after mercury sublimation in the furnace of boiling bed.

In the mounted apparatus the heating was electrical and temperature did not exceed $450{ }^{\circ} \mathrm{C}$. Since stibnite structure was very thin, stibnite was granulated. The coupling medium was aqueous solution of office glue.

Stibnite oxidation dependence on temperature, air rate and process duration have been investigated. Data on oxidation roasting at air rate $2.5 \mathrm{~m} / \mathrm{s}$ and temperatures $300-450{ }^{\circ} \mathrm{C}$ are shown in Table 9. As it can be seen from the table, the sulfur has volatilized for $99 \%$ with temperature increase, and time of antimony sublimation was from $9 \%$ to $17 \%$. In stibnite oxidation process non-volatile oxides $\mathrm{Sb}_{2} \mathrm{O}_{4}$, $\mathrm{Sb}_{2} \mathrm{O}_{5}$ are formed.

These oxides are restored till volatile $\mathrm{Sb}_{2} \mathrm{O}_{3}$ at temperatures above $1,000{ }^{\circ} \mathrm{C}$.

At that moment the following reactions are running in the furnace of boiling bed:

$$
\begin{array}{r}
2 \mathrm{Sb}_{2} \mathrm{O}_{4} \rightarrow 2 \mathrm{Sb}_{2} \mathrm{O}_{3}+\mathrm{O}_{2} \\
2 \mathrm{Sb}_{2} \mathrm{O}_{5} \rightarrow 2 \mathrm{Sb}_{2} \mathrm{O}_{4}+\mathrm{O}_{2} \\
\mathrm{Sb}_{2} \mathrm{O}_{5}+2 \mathrm{H}_{2} \rightarrow \mathrm{Sb}_{2} \mathrm{O}_{3}+2 \mathrm{H}_{2} \mathrm{O} \\
\mathrm{Sb}_{2} \mathrm{O}_{4}+2 \mathrm{H}_{2} \rightarrow 2 \mathrm{Sb}_{2} \mathrm{O}_{3}+2 \mathrm{H}_{2} \mathrm{O} \\
\mathrm{Sb}_{2} \mathrm{O}_{5}+2 \mathrm{CO} \rightarrow \mathrm{Sb}_{2} \mathrm{O}_{3}+2 \mathrm{CO}_{2} \\
\mathrm{Sb}_{2} \mathrm{O}_{5}+2 \mathrm{H}_{2} \rightarrow \mathrm{Sb}_{2} \mathrm{O}_{3}+2 \mathrm{H}_{2} \mathrm{O}
\end{array}
$$

\section{Conclusions}

The technology of mercury-antimony gold bearing ore processing of Djijikrut deposit is offered. The technology of vacuum distillation of antimony-mercury gold bearing concentrates of Djijikrut deposit and pyroselection of calcine after a 
preliminary distillation of mercury, which allowed us to obtain marketable products of mercury and antimony, is developed.

\section{Acknowledgments}

This work was supported by ISTC (International Science \& Technology Center), \# Project T-1598.

\section{References}

[1] V.V. Lodeyschikov, A. Panchenko, Basic technology of extraction of gold and antimony from complex ores, Intensification of the mineral processing processes, Science (1981) 189-193.

[2] Z.A. Zinchenko, M.S. Ismoilova, I.A. Tyumin, Enrichment technology of antimony-mercury gold-containing ores of Dzhizhikrut deposits, Mining Magazine 10 (2009) 80-81.

[3] P.M. Solozhenkin, Z.A. Zinchenko, Enrichment of Antimony Ores, Nauka, Moscow, 1985, p. 180.

[4] P.M. Solozhenkin, Z.A. Zinchenko, A.F. Emelyuanov, The study of antimony-containing ores flotation by new surface-active substances, Nonferrous Metallurgy 3 (1989) 6-11.

[5] Y.A. Chernikh, Z.R. Baratova, R.R. Rahimov, Complexation of Reagent "Oksafor-1107", Reports of the Academy of Sciences Tajikistan, Technics 30 (8) (1956) $5-11$.
[6] V.I. Zelenov, Method of Gold Ores Study, Nedra, Moscow, 1978, p. 302.

[7] I.N. Maslenickiy, L. Chugaev, V.F. Borbat, Metallurgy of Precious Metals, Metallurgy, Moscow, 1987, p. 432.

[8] Y.A. Kotlyar, M.A. Meretykov, L.S. Strizhko, Metallurgy of Precious Metals, Ore and Metals, Moscow, 2005, p. 392.

[9] M.N. Abdusalyamova, S.A. Gadoev, P.M. Solozhenkin, Vacuum metrical method for processing of antimony-mercury ores and concentrates, in: Proceedings of the Republican Scientific and Practical Conference, Innovation-an Effective Factor in Relations Between Science and Production, Dushanbe, Tajikistan, 2008.

[10] M.N. Abdusalyamova, S.A. Gadoev, O.I. Rachmatov, Vacuum treatment of the $\mathrm{Sb}-\mathrm{Hg}$ concentrates, in: Proceedings XI International Conference on Crystals Chemistry of Intermetallic Compounds, Lviv, Ukraine, 2010.

[11] M.N. Abdusalyamova, S.A. Gadoev, Vacuum distillation method of mercury-antimony concentrates, TJ Patent, 1000436 (2010).

[12] M.N. Abdusalyamova, S.A. Gadoev, P.M. Solozhenkin, Vacuum distillation of antimony-mercury gold containing concentrates, Reports of the Academy of Sciences Tajikistan, Technics. 54 (1) (2011) 74-79.

[13] T. Zhao, The Metallurgy of Antimony, China, 1988, p. 731.

[14] G.A. Shahov, J.J. Slobodskoy, Oxidation of antimonite, Svetnay Metallurgy 10 (2) (1930) 12-15. (in Russian) 